Article

\title{
Sustainability, Sociocultural Challenges, and New Power of Capitalism for Renewable Energy Megaprojects in an Indigenous Mayan Community of Mexico
}

\author{
Amina El Mekaoui ${ }^{1} * \mathbb{\infty}$, Rasikh Tariq ${ }^{2}\left(\mathbb{D}\right.$, Othón Baños Ramírez ${ }^{3}$ and P.E. Méndez-Monroy ${ }^{4}(\mathbb{C}$ \\ 1 Cátedra CONACYT, Centro de Investigaciones Regionales, Unidad de Ciencias Sociales, \\ Universidad Autónoma de Yucatán, Calle 61 número 525 entre 66 y 68, col. Centro, \\ Mérida C.P. 97000, Yucatán, Mexico \\ 2 Facultad de Ingeniería, Universidad Autónoma de Yucatán, Av. Industrias No Contaminantes por Anillo \\ Periférico Norte, Apdo. Postal 150, Cordemex, Mérida C.P. 97000, Yucatán, Mexico; rasikhtariq@gmail.com \\ or rasikhtariq@alumnos.uady.mx \\ 3 Research Professor, Centro de Investigaciones Regionales, Unidad de Ciencias Sociales, \\ Universidad Autónoma de Yucatán, Calle 61 número 525 entre 66 y 68, col. Centro, \\ Mérida C.P. 97000, Yucatán, Mexico; bramirez@correo.uady.mx \\ 4 Research Professor, IIMAS-Mérida Universidad Nacional Autónoma de México, Parque Científico y \\ Tecnológico de Yucatán, 5.5Km Carretera Sierra Papacal-Chuburna, \\ Sierra Papacal C.P. 97302, Yucatán, Mexico; erick.mendez@iimas.unam.mx \\ * Correspondence: amina.mekaoui@conacyt.mx; Tel.: +52-1-999-411-7214
}

Received: 9 July 2020; Accepted: 26 August 2020; Published: 10 September 2020

check for updates

\begin{abstract}
Sustainable development is an integrated blend of energetic, economic, social, environmental, and governmental actors, making it one of the most challenging and subjective aims of the United Nations. A sustainability project that does not consider any of these parameters can generate resistance among different actors of society. In this work, we have demonstrated that the traditional definition of sustainability encompassing economic development, environmental protection, and social justice does not adequately cover large-scale renewable energy projects. We have presented an illuminating case study of solar development in the Yucatan state of Mexico to show that the traditional three-legged stool of sustainable development fails to accommodate local power relations and their role in energy decision-making. This point is made through a substantive and illuminating ethnography of a solar project in the community of San José Tipceh, which involves the importance of energy democracy and understanding power relations in any assessment of sustainable development. These power relations are an important component of sustainable development, and all megaprojects, especially renewable energy projects, require special attention in the governance processes. Through an analysis of an example of implementation of a mega solar project, we argue that the methodology through which the power is exercised is an exercise of great importance because it leads us to a scientific discussion that structures an international reflection on sustainability. The case study consists of mixed methods, including several techniques to deepen the analysis of sociocultural aspects, and tries to present the limits and show the weakness of the sustainability perspective in such megaprojects. It is concluded that environmental justice as a basic element of the new era of renewable energies is limited and can generate social injustices. In the same way, this work shows how power is exercised in the implementation of energy projects and in the absence of equitable comprehensive governance that does not consider the local sociocultural contexts of the communities, resulting in the generation of new powers and permanent conflicts. At the end of this work, a framework to empower local sociocultural contexts for an equitable energy transition is recommended.
\end{abstract}


Keywords: sustainable development; energy democracy; indigenous community; renewable energy megaprojects; social resistance; energetic capitalism

\section{Introduction}

The urgency of environmental protection is evident in the face of the manifest damage caused by human action. In 1987, the concept of "sustainable development" was first formulated and used at the UN World Commission on Environment and Development [1] in the report entitled "Our Common Future" [2]:

"Sustainable development is development that meets the needs of the present without compromising the ability of future generations to meet their own needs. It contains, within it, two key concepts:

1. The concept of 'needs', the essential needs of the world's poor, to which overriding priority should be given.

2. The idea of limitations imposed by the state of technology and social organization on the environment's ability to meet present and future needs.

Thus, the goals of economic and social development must be defined in terms of sustainability in all countries-developed or developing, market-oriented or centrally planned. Interpretations will vary but must share certain general features and must flow from a consensus on the basic concept of sustainable development and on a broad strategic framework for achieving it."

This new formation has placed economic growth and social equity as the development objectives while equally presenting them as a new tool in the incorporation of sustainable use of resources. The approach, called Sustainable Development, integrates three aspects (social, environmental, and economic), considers development planning, where the effective participation of the actors is vital, and requires the adaptation of science and technology to human needs. It is not enough that investment projects are technically viable and economically profitable; it is also necessary that they must be socially desirable [3]. All these factors were taken into account by the United Nations General Assembly for the creation in 2015 of the Agenda 2030 for Sustainable Development, where 17 Sustainable Development Goals were proposed, forming an integrated and indivisible framework of 169 targets and 232 quantifiable indicators [4].

Sustainability is a human-centered concept that encompasses multiple aspects and objectives of different groups of interest. Sustainable development is not exactly measurable; it is a compromise between different parts of society, some of which try to represent our future generations [3]. In the present 21st century, it is no longer possible or sustainable to think of a development model disconnected from the ecological perspective [5]. Production processes must be clean; not only must they tend to reduce the use of natural and energy resources [6], but they must reuse waste, decrease the use of energy, promote the use of renewable energy [7], and take care of biodiversity and the process of normal reproduction of ecosystems. However, the concept of sustainability does not finish here because, while keeping energy in the context of sustainable development, the social [8] dimensions have equal importance. The production and use of energy must not only be compatible with the environmental priorities of society but must also be organized in a way that supports the social consensus that unites the social elements. According to the Rio de Janeiro Summit [9], the notion of sustainable development has traditionally occurred around three main fronts that are ratified even in the Johannesburg political declaration $[4,10]$ : The commitment to "advance and strengthen interdependent and mutually reinforced pillars, such as economic development, social development, and environmental protection, at the local, national, regional, and global levels" [11]. 
Currently, there is talk of a new dimension of sustainable development that incorporates elements of a political and institutional nature, which are considered to be favorable elements due to the role played by the state and institutions as guarantors of harmonization scenarios in the economic [12], social [13], and environmental [14] spheres. The integration of these different aspects is presented graphically in Figure 1.

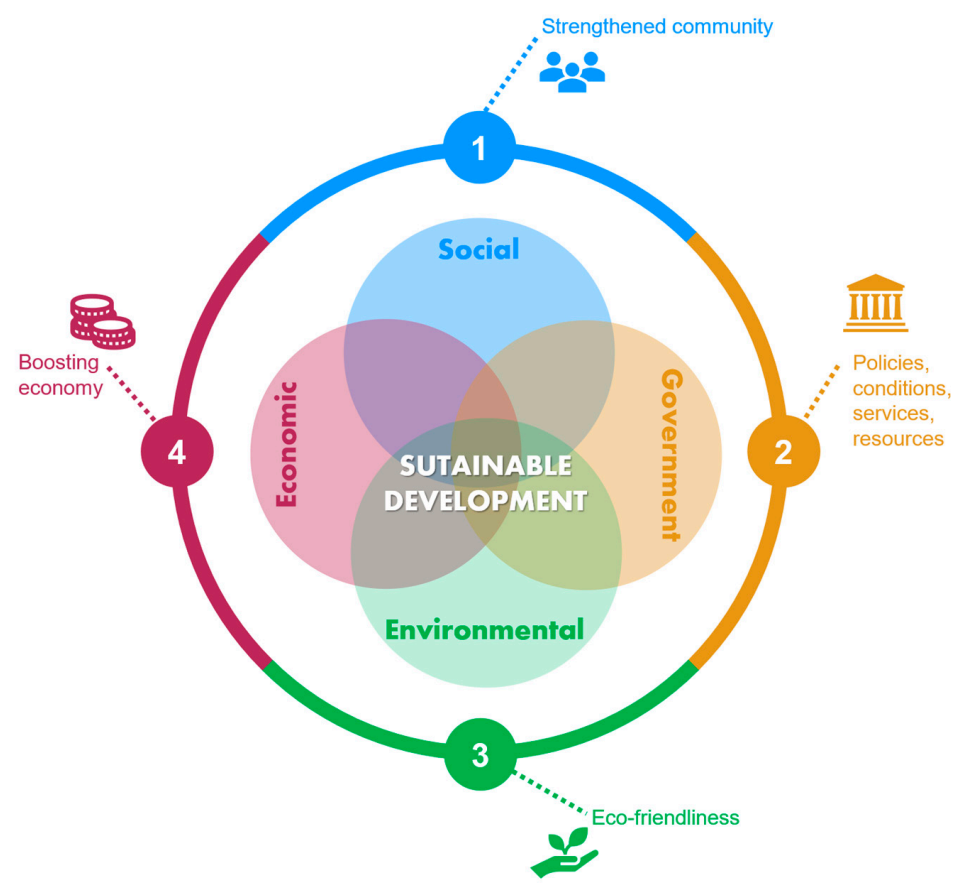

Figure 1. The concept of sustainability is a successful integration between the environmental, governmental, economic, and social aspects, as presented in the case study of this work.

Another key concept in the search for sustainable development is that of energy democracy. Unfortunately, this concept does not have a univocal definition. This is in juxtaposition to the dominant neoliberal system. Energy democracy seeks that energy users and workers have power over the entire sector. Therefore, energy democracy must be conceived as an ongoing democratization process within the framework of the historical and geographical circumstances that each region experiences. In this way, energy democracy turns into continuous regional struggles over who owns and controls energy, and how, where, and for whom it is produced and consumed [15].

Energy strategies in the context of the transition are not possible without considering the factors that must be taken into account when defining the strategic plans, which makes us think of the need for energy democracy in the first place as a guarantee that each citizen has the same access to energy services (thermal comfort, means of travel, household appliances, lighting, etc.) and to provide the economic world with the energy resources necessary for the production of goods and services for the communities and homes in worthy economic conditions. Secondly, the need to guarantee the security of supply, routing, and distribution of the energy is necessary to provide energy services. It is necessary to recover the idea of energy as a tool to satisfy needs in a context of finite resources and inequity under a logic of rights.

The current energy transition represents the need for a radical change in the way we think about energy. Beyond a simple technological evolution of our product mix, it is about building a needs-based energy supply and then, using effective transformation means, determining our production. This chain, from the need for energy services to production, must respect the challenges of our time and the principles of sustainable development.

From an environmental point of view, this implies limiting greenhouse gas emissions and industrial risk, nuclear risk, space consumption, etc., as well as ensuring a minimal impact on biodiversity. 
The "social pillar" consists of guaranteeing access to energy comfort acceptable to all in acceptable conditions, eliminating low-income households from their dependence on expensive and polluting energies through emergency devices to combat energy poverty, but especially giving them access to very energy-efficient homes and equipment. Finally, opportunities for economic development range from the industrial production of efficient or renewable energy production equipment to agricultural and forestry activities in construction, services, and engineering.

Considering these ideas, we must present our research question on the sociocultural limitations of the energy transition, which limits energy democracy and puts development governance on the table for criticism. One of its reasons concerns the conventional implementation trajectories of sustainable development programs, which are currently in the top-bottom (global to local) order (see Figure 2), where global implementation programs do not review the complexities of the local ones, which can finally generate social disagreements, conflicts, and social unacceptability. Finally, this will contribute towards the unsuccessfulness of sustainable development, yielding ineffective energy transitions. In other words, there is always a gap between global sustainability policies and the local implementation, especially the interlinkages [16], partnerships, and agreements between the communities and the companies, as suggested by Hale et al. [17], who stated that the audits are well developed in terms of environmental requirements, but are often less directly engaged with issues of social sustainability. Phondani et al. [18] emphasized the consideration of the indigenous practices of agroforestry systems in the Uttarakhand in the Himalayan region. Meadows et al. [19] presented the environmental and sociocultural impacts of extractive industries working on the lands of indigenous people and recommended to maintain transparency in the governance and assurance processes. Karanasios et al. [20] implemented a multi-layer perspective assessment to examine the diffusion and governance processes of the introduction of renewable energy technologies in the remote indigenous communities of Canada. Schwoerer et al. [21] predicted the food-water-energy nexus of wild food systems through the prism of energy transitions in isolated indigenous communities of the Arctic and Subarctic regions. Fernández-Llamazares et al. [22] presented a socio-cosmology connection to sustainability among the game masters of the indigenous people across the Amazon Basin. To further strengthen our argument, we have presented a list of case studies in Table 1.

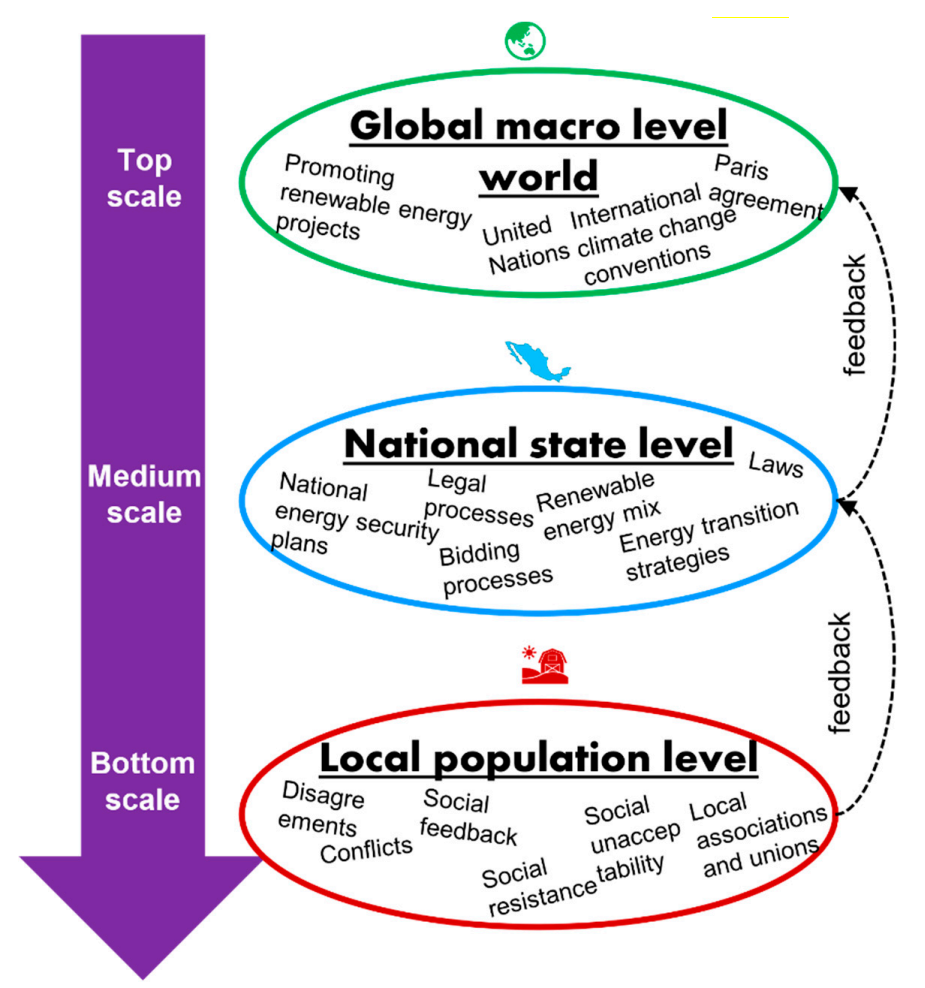

Figure 2. Conventional implementation trajectory of the sustainable development programs. 
Table 1. Literature review of different available studies correlating environmental and social injustices.

\begin{tabular}{|c|c|}
\hline Reference & Summary \\
\hline [23] & $\begin{array}{l}\text { This work presents a case of South Africa to understand the renewable energy transition } \\
\text { and mentioned that it is a simultaneously spatial and political injustice. The authors } \\
\text { argued that energy transitions are intrinsically bound up with both the materiality and the } \\
\text { historical and contemporary politics of land. }\end{array}$ \\
\hline [24] & $\begin{array}{l}\text { This article combines the theoretical base for defining the social, environmental, and health } \\
\text { injustices of the coal industry among the local communities. The authors pointed out that } \\
\text { the injustices, conflicting priorities, and power asymmetries are a triangular problem } \\
\text { between the industry, government, and inhabitants of mining communities. }\end{array}$ \\
\hline [25] & $\begin{array}{l}\text { The energy transition of India increasingly prioritizes solar energy infrastructure to meet } \\
\text { global sustainability goals, but this infrastructure requires an enormous land area. } \\
\text { The authors presented the case of the solar infrastructure of Kerala, which is associated } \\
\text { with social injustice. It is recommended to consider the local context while addressing the } \\
\text { energy transition. }\end{array}$ \\
\hline [26] & $\begin{array}{l}\text { The authors have analyzed the energy efficiency policies in housing and mentioned that } \\
\text { fostering the energy efficiency improvements has led to rising protests and conflicts } \\
\text { because investments made in retrofitting became a means of speculation and displacement } \\
\text { of low-income residents. The authors have used the social conflict theory to interpret the } \\
\text { different forms of conflicts in the case of Germany. It is also discussed that the state has } \\
\text { implemented energy standards for buildings without considering the socio-economic } \\
\text { status of residents and has generated a conflict between the housing companies } \\
\text { and tenants. }\end{array}$ \\
\hline [27] & $\begin{array}{l}\text { This paper explores the drivers and implications of Bulgaria's renewables expansion to } \\
\text { assess general expectations of influential factors shaping renewable energy transitions in } \\
\text { the context of poor states. }\end{array}$ \\
\hline [28] & $\begin{array}{l}\text { The authors used data from the American Community Survey, U.S. Wind Turbine } \\
\text { Database, and the National Renewable Energy Lab, and outlined the current landscape of } \\
\text { wind energy injustice along social dimensions. }\end{array}$ \\
\hline [29] & $\begin{array}{l}\text { Editorial note from The Lancet Planetary Health has mentioned that environmental racism } \\
\text { shows that environmental and social issues cannot be neatly separated from each other and } \\
\text { concluded that environmental protection policies must not be considered individually, } \\
\text { and the individuals most affected by them should be considered as much as the } \\
\text { average population. }\end{array}$ \\
\hline [30] & $\begin{array}{l}\text { Emphasis is given that social research should be fundamental in the planification of the } \\
\text { energy transition of Mexico through examples of the implementation of renewable energy } \\
\text { projects that caused social opposition and conflicts in indigenous communities. }\end{array}$ \\
\hline [31] & $\begin{array}{l}\text { A case study is presented to evaluate the social acceptance of wind energy power in } \\
\text { Shandong Province, China. It was concluded that residents may accept renewable energy } \\
\text { due to their concerns about environmental issues. }\end{array}$ \\
\hline [32] & $\begin{array}{l}\text { Presented three approaches of the social science research of renewable energy projects; } \\
\text { these are normative, criticism, and critical approaches. }\end{array}$ \\
\hline [33] & $\begin{array}{l}\text { The authors say that framing discrepancies between the policy elites and residents } \\
\text { represents a reflection of procedural injustice. }\end{array}$ \\
\hline [34] & $\begin{array}{l}\text { The authors argued that solar products are celebrated as encouraging development, } \\
\text { and there is a limited discourse about the consequences of relying on off-grid solar markets } \\
\text { to address energy poverty. The authors presented a case study of Malawi to demonstrate } \\
\text { how a poorly regulated solar market has generated injustice in the local settings. }\end{array}$ \\
\hline [35] & $\begin{array}{l}\text { Research was carried out based on a qualitative methodological framework, and it was } \\
\text { concluded that conflicts around non-conventional renewable energy projects would be } \\
\text { linked to a reduction of ecosystem service provision in the context of La Araucanía, Chile. }\end{array}$ \\
\hline
\end{tabular}


Table 1. Cont.

\begin{tabular}{|c|c|}
\hline Reference & Summary \\
\hline [36] & $\begin{array}{l}\text { A case is presented through examples of wind energy projects in Southern Mexico. It was } \\
\text { concluded by the authors that a bottom-up approach is recommended to understand the } \\
\text { complex concepts of energy justice with the indigenous community. }\end{array}$ \\
\hline [37] & $\begin{array}{l}\text { The authors emphasized that sustainability and social justice deserve attention in the } \\
\text { sustainable energy transition plans. }\end{array}$ \\
\hline [38] & $\begin{array}{l}\text { The authors highlighted that, when it is aligned with environmental problems, political } \\
\text { ideology determines the public support only. The authors emphasized that Ontario, } \\
\text { Canada needs more effort to increase the level of public support while encouraging the use } \\
\text { of renewable energies. }\end{array}$ \\
\hline
\end{tabular}

In this context, the arrival of energy megaprojects in Mexico brought many inter-linked scenarios, mainly owing to the perspectives of energy companies, government policies, and the local communities. Zárate-Toledo et al. [39] reported that the wind energy projects in Tehuantepec, Mexico resemble an extractive model and have no consideration for the local cultures. Mejía-Montero et al. [40] presented the role of social resistance in shaping the energy transition policy of Mexico for the case of wind energy power in Oaxaca. Martinez et al. [30] argued that these renewable energy megaprojects have caused significant social opposition and even conflicts in the indigenous Mexican community. Likewise, the arrival of the energy megaprojects in the Yucatan state (see Figure 3) of Mexico is an intensely complex and heterogeneous issue, which explains the problems and reactions of rural communities, especially in the case of an indigenous community living in a rural zone called San José Tipceh, where their resistance and the process of negotiations have been very important from the anthropological point of view.

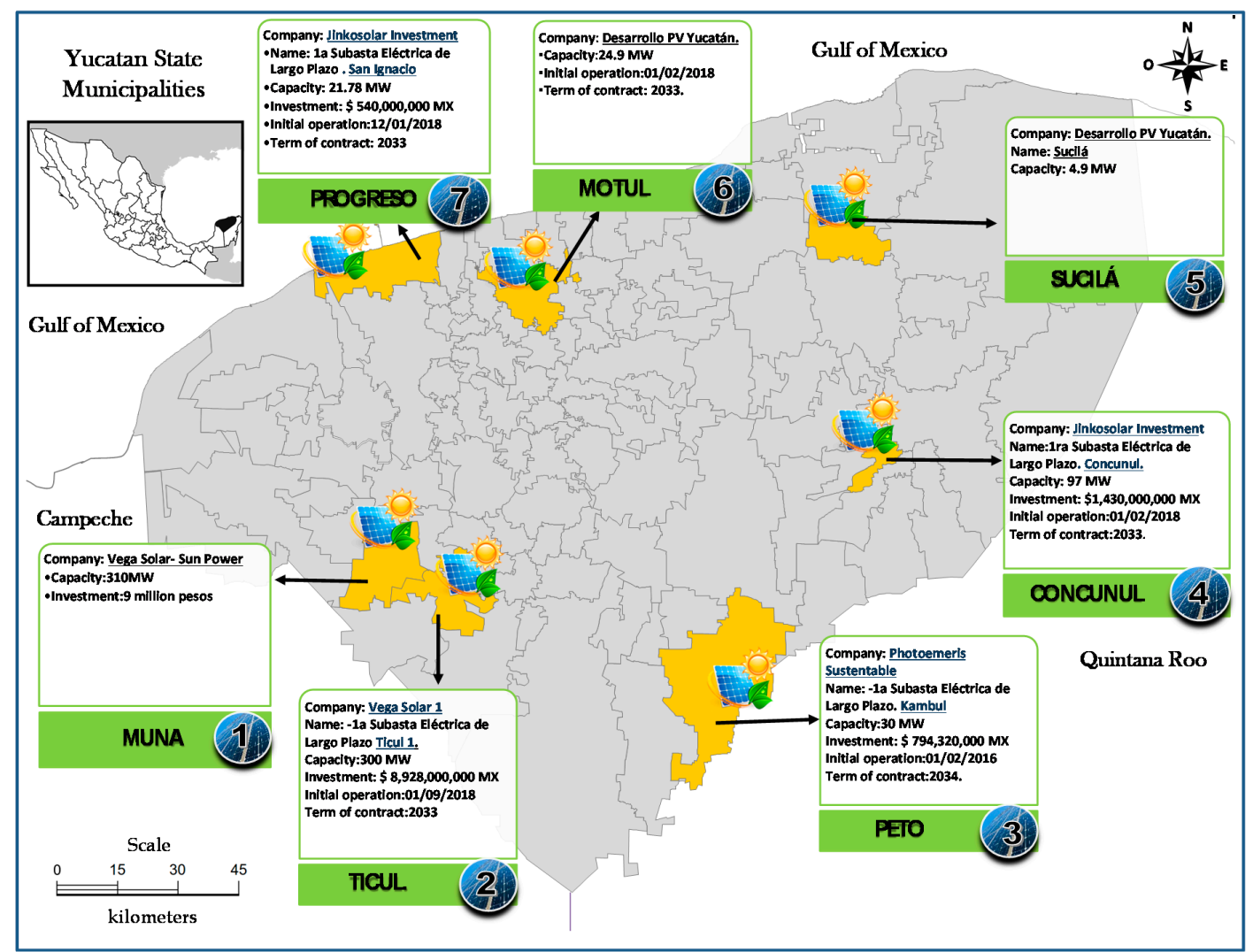

Figure 3. Locations of different central photovoltaic megaprojects in the state of Yucatan, Mexico. 
In the present scientific work, through an ethnographic investigation of the social, cultural, and political processes before the implementation of the San José Muna Solar Park, it is shown and analyzed how the community reacted and how they lived the implementation experience; the objective is to understand why sustainability is still a paradigm with sociocultural limits today. In the case of San José Tipceh, an analytical description of the limits of the project and the double liminalities on the part of the main actors (communities, state, and companies), as well as their forms of negotiations during the implementation process of the Ticul A Solar Park (see Figure 3), is presented.

The manuscript is organized in a total of five sections. Section 2 presents the methodological framework and research techniques; Section 3 presents the details of the interactions between solar energy investments and the Mayan community. Section 4 presents the results and discussion, which present the roles of different state, organization, and community interactions; the implementation of this project is also discussed in terms of gender discrimination, and, finally, the work is concluded with recommendations for avoiding social conflicts.

\section{Research Techniques and Methodological Framework}

The ethnography presented in this article is for the territory of the rural community called San Jose Tipceh located in Yucatan, Mexico. The work shows a classification of different ways of exercising power in the Mayan communities; in this case, this was done through observation and the study of the community and ejidatarios (see Appendix A for the definition of ejido) during the implementation of the Solar Park in community.

The methodological framework of this research considers ethnography not only as a method that describes a complex reality and the invisibility of social reality, if not also as one that allows us to bring project proposals to the research subjects and, thus, to strengthen the community as an actor of local development in its territory. It is necessary to clarify that the research topic brings us closer to the sensitivity caused by the dangerous triangle of topics for researchers, such as sexuality, religion, and politics, which require methodological approaches and solid theoretical frameworks that allow us to understand them. Our research process has not only been complicated and uncomfortable, but also enriching; the contradictions that exist between practice and discourse in the field of energy sustainability helped to deepen the main research question.

The subject is not only sensitive and controversial, but it also finds itself at an intersection of several paradigms, where the scientific paradigm is what structures our approach. Our methodological dynamics for the collection of information describe the liminalities experienced in time and space, which put before us a series of negotiations with the methods and techniques among which there was always a need to search for an alternative technique to try to understand the disaster that lives between today and yesterday in the community.

To collect the necessary data, we used various techniques to evaluate our research problems, which are presented in Figure 4. The fieldwork was carried out in the San José Tipceh community during the period 2019-2020 while dealing with subjects like authorities, the ejido, and the community, which are discussed in the subsequent sections. 


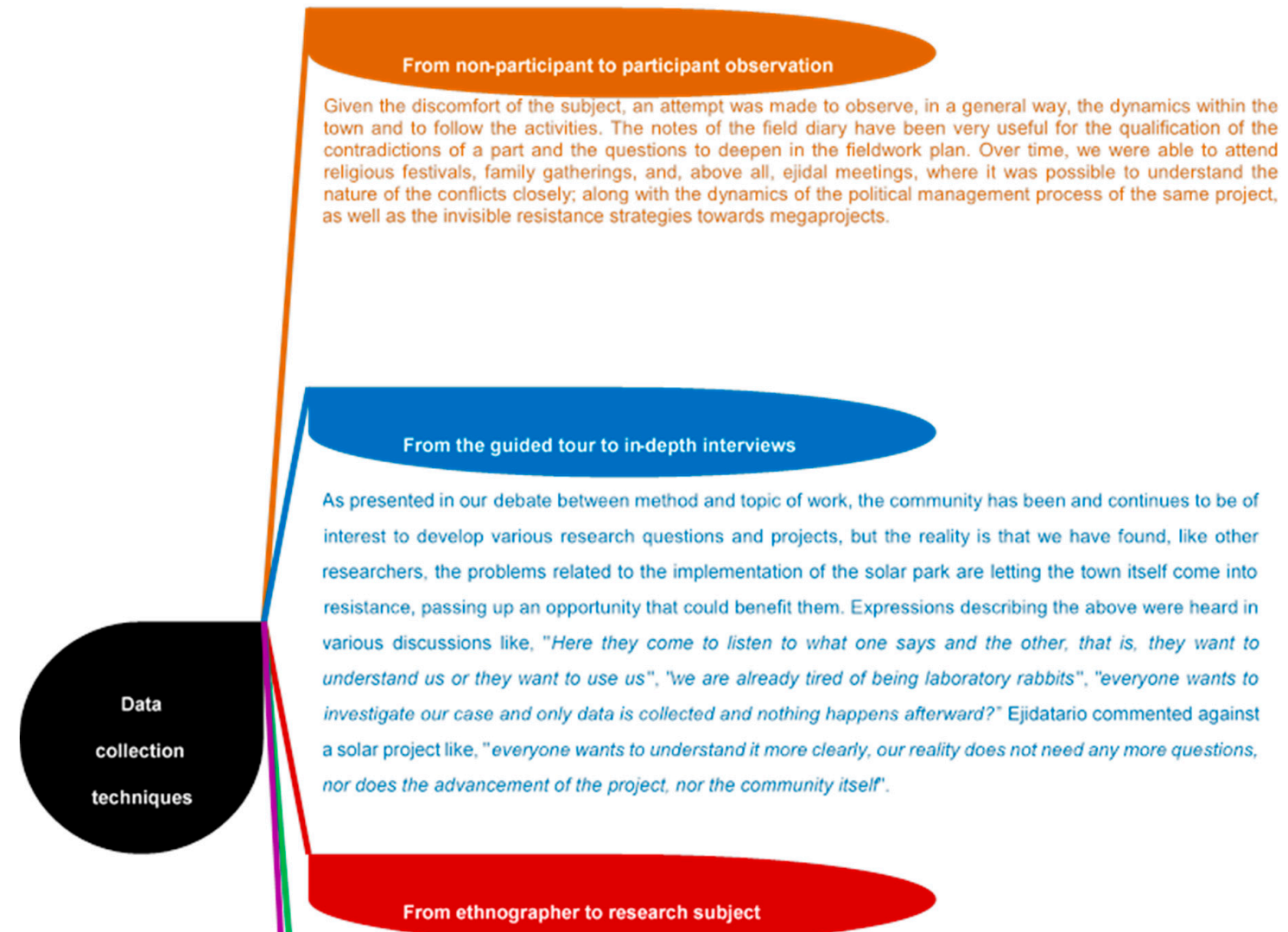

What we want to mention here is the change that was experienced in the field, rather than trying to establish relationships of trust and select people for data collection, on several occasions the roles were changed and we were studied, mainly with the ejidatarios who were against the project. They have their questions trying to identify our position that is not clear to them and thus be able to determine what elements they are using for their resistance plans. They asked about our views on transition, efficiency, megaproject, power, and community, etc.

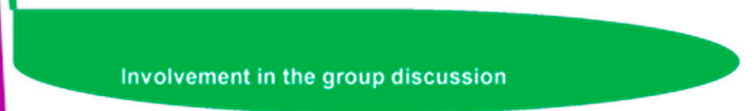

Similarly, in the dynamics of our research, due to the nature of the topic and the use of space, it was difficult to organize focus groups at first, so we worked with groups without determining technical aspects for the focus group, where we tried to accommodate some questions according to their discussions. This was very useful because it defines the levels of conflict, and cohesion between them.

Being a silent anthropologist

In this sense. from the context of the field. we can conclude that due to the complexity of the issue to be dealt with the community that is against the project, the community confuses us with politicians or people from the company. The interest of these groups in accumulating opinions about environmental damage, megaprojects, indigenous peoples, the future, energy, and socio-environmental poverty is noted. We have noticed that these people use their recorders without asking for permission, which allows us to conclude that being "silent" turned out to be a better strategy to avoid conflict and give them time to talk, while we can understand and observe their dynamics and discourses.

Figure 4. Research techniques to gather useful data.

\section{Mayan Communities: New Territory for Investments in Solar Energy}

San José Tipceh (SJT) is one of the communities near Mérida, Yucatán, located 5.1 kilometers from the town of Muna, where two tourist routes fork: the Puuc route and the Conventos route. Located on the route of the convents, SJT has 513 inhabitants, of which 245 are men and 268 are women.

With the arrival of the solar project in the community of San José Tipceh, a new social chapter was opened that allowed us to understand the limitations and transformations that are occurring with new 
investments in clean energy, as well as the impact of the implementation process. We analyzed the practices of power and the context of social acceptability within the framework of megaprojects.

According to the narrations, of the 102 ejidatarios, five of them are against the project being established in the community. Three ejidatarios in this group of five are the most radical, and do not collect the rent that is being paid under the agreement achieved in the community consultation process. Furthermore, it was determined by the authorities that the signatures of the dissidents were pending for the project to begin in 2020. Until the last dates of fieldwork (December 2019), no judicial authority had ordered to stop the project.

Asking how the project got to the community is key to understanding what happened, what is happening, and what may happen in the future. Don Salomón, who was said to be the heir of the Tipceh hacienda, is a key character in this story; as of today, he remains the sole owner. Even though there is a legal dispute, the community occupies the lands that belong to the hacienda. The following testimony by one ejidatario is strong: "Here in San José Tipceh, we all feel the duty to obey Don Salomón, who has done many favors for the community."

The first offer to buy the land from the province of Don Salomón, who "... made his economy and businesses grow by supporting our work, and he contacted us with his people to offer us to sell the ejidos in exchange for a few pennies while he took care of the company," according to one ejidatario.

In the last several years, most of the ejidatarios have stopped working in the lands due to various environmental, social, economic, and territorial factors. Don Salomón affirmed that he buys the land to grow citrus fruits, which would generate jobs for the townspeople.

Don Salomón offered help, meals, and other promises, including scholarships that promote the social development of the community, to women and men. The environmental scenario and the promises influenced the ejidatarios to agree to the sale of the land and to take the advances.

"The project never came directly to us so that we could understand and clarify our doubts. It was from Don Salomón that he promised to buy the land-according to him, to plant orange groves. When he established that, he gave food, small grants for the kids' school, and meals until people got drunk, which is what most people love to do here," said a woman from the community.

A few months later, the community received information that everything had been a great deceit by Don Salomón. An informant who lives in the municipality of Muna described what happened as a trap by Don Salomón to make more money. He was also supported by the authorities along with some other ejidatarios, without forgetting the company that hoped, according to the declarations of both, to accelerate the time of the legal process for the beginning of the project. From our perspective, this can show us a structure of (1) permanent domination and (2) negotiation in which the indigenous communities are made to submit.

\section{DOMINATION STRUCTURE:}

“This project does not care about our community; unfairly, it ended up unbalancing us more than we already were. The company and the government contacted the most capitalist person in this community, Don Salomón, who made his fortune grow due to the work of the community. We have all worked for him and to grow his capital. Most of the houses belong to him. We only own the ejidos that the government gave us through agrarian reform and ended the era of green gold. The henequen was not only a source of income and did not only give work to families, but it was also something that ensured that we would continue having income; even though it was little, it was permanent." "In my opinion, with the arrival of the unjust project, they tried to deceive us with Don Salomón, who gave us a few pennies to accept, because nobody wants to work in the forest, and for most of the young people who travel outside the city, the Edjidal land is far away. Most of the ejidatarios need this income from the offer of the purchase of the land and, in addition to the purchase, from working on it. After a while, we realized that Don Salomón did all that to be the sole owner of the ejido rental project with the company, and also the sole owner of the land and houses where we 
have lived since we can remember. He wants to be the sole owner of the company, with which he caused more than a conflict between ejidatarios, but also problems among the inhabitants of the community."

\section{PERMANENT NEGOTIATION:}

"This project came here that way because we lack a lot, and when entering in that way, they knew that it could be done because most of the ejidatarios do not have a decent income. The milpa is over and they are old; everyone thinks that any penny will be welcome," said one ejidatario who is against the project. "This solar park came that way because we, as a community, are no longer a single hand; just seeing that the politicians and the ejidatarios were in the context, as well as the women and people of the community, whenever there is more money, there will be more demand. The damage was already done; it only located us," said another ejidatario. "In general, the context of the project must be understood because the contact was made with the only person in the city who gave jobs. It is only necessary to clarify that there is a difference in the sale of land so that it has one use and when it is suddenly given another use. It can be said that the project reached people in disguise and invisibly."

The previous testimonies show us the different types of power implementation in the community and how they are exercised by each actor. In the next sections, we will show with testimonial evidence that, beyond energy sustainability, the issue of social impacts and their management is related to the problem of governance. The presence of new infrastructures in communities-which are, in themselves, too sensitive to external interference-polarized these governance deficiencies.

\section{Results and Discussion}

The section is divided into two parts. In the first part, the exploitation of the implementation of power by different actors is presented, followed by a discussion on the permanent sociocultural limitations and the absence of energy democracy.

\subsection{Energy Transition between New Power and the Liminalities of Sustainability and Energy Democracy}

In this section, a systematic description is presented of the triple face of power between the interlinked conflicts of governance, Ejidal territory, and the indigenous community, which is expressed in Figure 4. It states that the triple face of power comes in the form of economic power of the company, political power of the government, and social and cultural power of the community, territory, group of civil societies, and many others. This generates new types of domination, discrimination, negotiations, conflicts, and fragmentation, which finally limit sustainable development and generate an absence of energy democracy. This discussion is further extended in Sections 4.1.1-4.1.3 with evidence from the locals.

\subsubsection{Political-Economic Power of the Company and the Government: An Example of} Unethical Power

The analytical exercise that we intend to do in this work has the essential objective of approaching the contexts of the implantation through a scientific paradigm to understand the methodology of the implementation process. With the power of the authorities reflected by the statements and with the help of notes of observations in the field, it is possible to speak of a power that did not only come to establish communication among different groups.

The authorities of the state are the actors, as described by the interviewees, who always remained as mediators (see Figure 5) between the community, the ejido, and the company. They always had to give more explanations, to inform more, and to have fewer errors, according to their statements. They came up with strategies to make the project. Several opinions were criticizing the state and federal power, claiming that it was manipulative, corrupt, dominant, and lacked professional ethics [39]. 


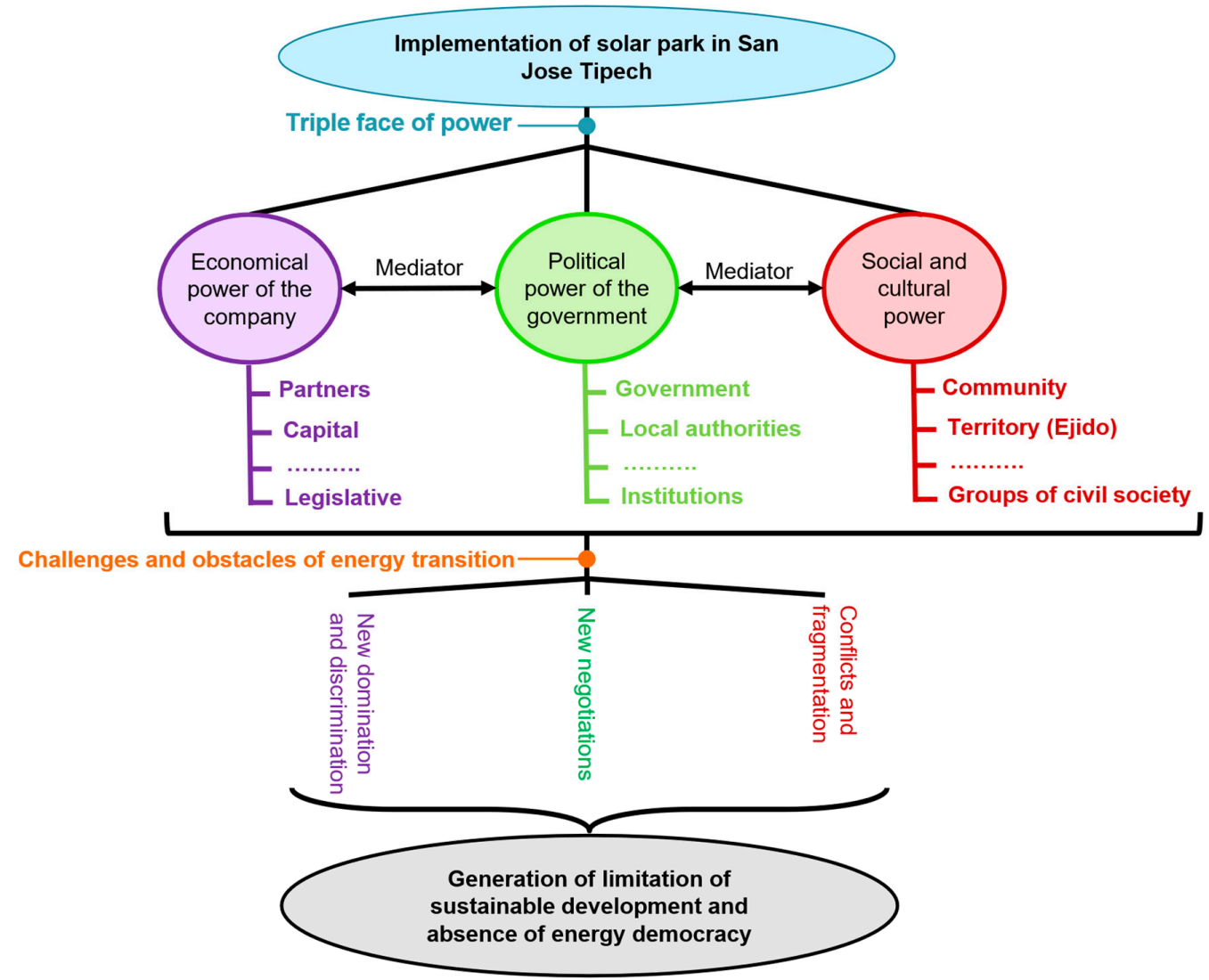

Figure 5. Structure of power implementation and the limitations of energetic democracy and sustainability for the case of San José Tipceh.

At this point, there are mixed opinions. A real conflict is located where people begin to narrate the experience of the town; many speak of recognizing that what the government did was to move forward, others describe the power at that time as responsible for the abuse by the sole owner of the hacienda, and some even accuse the current power.

Talking about how power is exercised through the analysis of an example of implementation of a mega solar project is an exercise of great importance because it leads us to a scientific discussion that structures an international reflection on sustainability. Energy transition and sustainability in Yucatan are very important issues, and to understand them, one cannot ignore how power was exercised by the authorities to establish these agreements and negotiate the rights of the towns.

How power is applied in the implementation is not different from how power is exercised in other projects; it is a model of neoliberal governance. It is still a part of the present with the energy transition, where the socio-environmental conditions in the area were taken to be delimited, as the authorities reported in their statements. In the beginning, the town would have been sold if these sales had been allowed, especially since there were opinions that the former commissioner knew from the beginning of the project.

"Well, here we think differently, as we have always come to accept what is offered, especially from the government; almost nobody got upset. It did not take long until the presale. Everyone now says it was out of necessity, but still, because there is plenty of trust in the government, we have also had the habit of acting and less that of asking". (field, 2019-2020)

At this level, one can speak of the tradition of community power, where people resist little and support what comes from initiatives, especially when it is related to an economic benefit. 
"Here, money is always a blessing with what they come to offer us because the people here need it, but we did not doubt until that day we went up; even both of them had doubts about why Don Salomón would want to buy the entire ejido". (field, 2019-2020)

The aforementioned observations allow us to reflect on the concept of resistance according to Jemas Scott [41-43], who maintains that the central element in distinguishing resistance in the collective sense is communication between subordinates regarding their common situation of subordination while developing modes and strategies of opposition to such subordination. From this perspective, we can understand what we call the dynamics of the authorities towards the community; among them, there was a change of position of subordinate power, which ended with the use of various strategies by the authorities to find a way to sign the agreement.

According to the narrations of the community, everyone came up to speak with the authorities and tried to find how to balance the implementation process, consultations, and contracts, and even how to manage various conflicts.

"Here, about the authorities, no one could understand their role; they seek to balance between us and the company, up to where they defend us. I really cannot confirm it, but they did try to bring that to a successful conclusion because I said yes". (field, 2019-2020)

In this sense, other statements try to show that the authorities agreed to subordinate themselves because they are "complicit and corrupt".

"Here, nobody will tell me how and to what extent the authorities are in favor of the company. If everyone who has money becomes a subordinate, it is because it suits them, as do their strategies of calming down and being part of the protocol with the effort to talk to and invite the community. After all, the bites were not lacking; even I said that the first business was going to leave us with nothing. I was supported by the former commissioner; the current one did not respond. He tried to be gentle, but they are the same, liars and corrupt."

Everything that is happening finds explanations and similarities in the content of James Scott's first books [41-43] — The Moral Economy of the Peasant (1976), Weapons of the Weak (1985), and The Dominated and the Art of Resistance (1990)—where elements connected by the same common thread are located. From the study of class relations in Southeast Asia, he manages to develop his particular theory on domination, hegemony, and resistance. Power and resistance remain empirical elements that bring us closer to how power is exercised among various actors, where resistance turns out to be a normal process. As discussed in the next section, according to us, reaction became art. As shown in Scott's work [41-43], it is an art with several aspects, where his objective is to convince the other by having arguments to strengthen the resistant part and weaken part of the power.

\subsubsection{Ejido and Community: A New Alternative Sociocultural Power with Limits}

The task of classifying the resistance dynamics during the implementation of the Solar Park in the community of San José Tipceh, Muna Yucatán was not only a methodological exercise to respond to the problems of our research and validation of the hypothesis, but it was also a journey through the memory and forgetfulness of the population through the records made in various meetings with the community, sometimes disturbing, but at the same time, it was a part of the past and they wanted to forget it.

Ejidatarios have dual membership in the ejido and the town. In the community, they have a double valence: As owners of the agrarian rights to the land that the project will occupy and as residents, in this sense, it is a group with more decision-making power than the rest of the residents. For this reason, among other things, they receive more money for renting the land than residents. Previously, the ejidatarios were not richer or poorer than the rest of the residents. The terms negotiated with the government and the company, without intending to, become agents of social inequality. 
Addressing questions to the inhabitants, ejidatarios, and authorities was uncomfortable. People want to avoid those memories, especially when talking about the conflict that has been most characteristic of the present and the recent past.

From the first day, the energy company arrived. As this work describes, there was an immediate reaction from the community and especially from the ejido to such an extent that they began to organize to end the purchase of the ejido, which led to the stoppage of the presale with Don Salomón, and thus the start of new negotiations with the same company, which, from the beginning, was not only open to discussions of various offers, as we can see in the following statements:

"Listening to what the company mentioned on this day, we did not have to wait another minute, as we had made the decision to paralyze Don Salomón and to recover our ejido land. It was the day to end everything; not only to cancel the sale of the land, but also to start a new negotiation with the company until achieving what can be called an achievement today". (field, 2019-2020)

The game of resistance arises from the change of role and the position of power of the ejido, which was established as a dynamic of the first level of resistance. These realities in San José bring us in a very punctual way to the Giddens [44] model, where he affirms that "all people and communities have power in different spheres and can, with greater or lesser effectiveness, exert pressure on others." What Giddens [44] describes can be observed in one way or another in the community of San José Tipceh, where the ejido, as a group, regained a power that they were about to lose; this power allowed them to make decisions and act according to the situations that arose, and the pressure they applied was necessary.

"We really must recognize the work done by the ejido. We not only have to recover the ejido land that we were going to lose, but also come to have equal power. The event that happened has made us work again as a community to fight for our rights". (field, 2019-2020)

In the same context, the new power that the ejido had with these new dynamics in its relation to energy investments at the local level, which is quite limited in its structure, is discussed.

"From this day on, the ejido feels value; unlike before, we will understand that the land is worth more than we have thought, and if we protested against Don Salomón, it is because we did not agree with what he had as a plan, so to fight him well, the ejidatarios did the right thing". (field, 2019-2020)

It can be said from the opinions that the ejido is an actor that came to regain its power and showed that it must always fight as the only power in the community, which gives another image to the ejidatarios that go against what the group thinks.

“Here in San José Tipceh, yes, we came to fight for the ejido, which, in the end, didn't go to a complete sale. That is why we are always at the forefront; we are not going to lower our level. Those lands that are for urban expansion of the community, where we all have rights, from time to time, they kept telling us that they belong to Don Salomòn. We are not Don Salomòn; here, we continue struggling against the company and everyone. Even the authorities are satisfied with what little is given to them, so for us, the fight is not over. We would have to go to Panama and to contact academics and international foundations to know our rights and our power. We will be the strongest so that our lands are respected". (field, 2019-2020)

In this sense, the new face of domination shown by the affirmations of this group can be concluded; now, using the territory, they try to control the reality, knowing that without their signatures, the ejidal land cannot be used, and new negotiations will always arise in different forms of resistance. 
Regarding the powers of the company, the ejido, the community, and the owner of the hacienda have almost started a discussion about a new era and a local context since the arrival of the solar megaproject. All this has a meaning and validity according to the contribution of Richard Adams [45], where he declares that "power is the control that someone has over the environment of another." In our case study, the territory, rather than authority, is a power of negotiation and domination in a specific context.

Always, this power game that becomes resistance is a model that Foucault [46-48] taught us in his work, which is explained in the social realities in societies over time, as well as in the changes and transformations. From the specific framework of our work, that makes us wonder about the new power of the territory in the face of new energy investments, where the ejido demonstrated that it can not only paralyze the presale, but can also affect the progress of a megaproject. This model of San José explains to what extent power, when one has it, can force one to do what one does not intend, or what one has thought. This is the case of the company, which, according to them, came to completely change its plan, and its accounts are shown in the following statement:

"Of course, no one can deny that the company assumed the loss of the money that we have not returned to Don Salomón. They offered us more than they were planning to give to him. They tried to offer us even more than they intended. That is, our pressure turned out to be powerful, forcing even the authorities to submit to what we thought. That, of course, was the first time we have lived as ejido and people. I still keep asking how long and if they gave us what we asked for. I even got to hear that the company is leaving, and I hoped that it would be true". (field, 2019-2020)

The following brings us closer to a precise definition by Max Weber, who defines "power as the ability to force people to do what they do not want to do"; without a doubt, that definition clarifies to us what the role and the capacity of power are when it is executed in its entirety. In our research, we came to identify what Max Weber explains, that power can arrive at what can be called uncontrollable power. As inhabitants, some ejidatarios came to define it as passive power, as shown by the following comment: "Here, things have already gone over the limit; the company has done everything they were asked to do, and the last contract was signed with the presence of lawyers from both, but they continue playing and pressing us. To me, it seems an abuse of power on their part. What is worse here is that they are hurting us. If we are the majority who are in favor, of course, the community is with us, and with a minority, you can speak of excess pressure, but they are manipulating it" (field, 2019-2020).

There is a discussion of the new power that these communities are taking, from the new value of their lands to the agreements that are sought during the consultations to test those projects. At the same time, this discussion analyzes how the subject approached a model of how the power works in rural communities, while most of the settlements remain between capitalists, authorities, and companies, but the case of San José is another case. Reaching this last level brings us back to the basic discussion, where all the actors were a part of the power and all have come to resist according to the different contexts and the life of the implementation, but describing this process brought us closer to new realities and social fragmentations that have arisen since the arrival of the megaproject.

In the same way, we can explain that, in the power game applied in the case of the megaproject, there is no talk of a form of power that came especially with clean energy. This is a model that has worked in several programs, where the authorities have the same mechanisms in reaching the energy transition. In various contexts and declarations, it is shown that these are new sustainable policies with global models; these are still neoliberal policies subject to a context of national and local power that, according to our perspectives, should be reflected with new models of the design of those policies using a socio-environmental approach as an emerging condition, especially in rural Mayan communities, such as in our case study. 
Returning to Ortner [49], who affirms that the resistance category, even when it is ambiguous, is reasonably useful, this affirmation allows us to understand the strategies and dynamics on the part of the company as resistance practices to continue with the plan for the implementation of the draft.

Several ambiguous actions happened, but they were advantageous. In the case of the study, what the company faced was an inseparable blow, which disordered all its calculations. As the data show, the company came to solve problems that it had not initially considered.

“The company returned the money to Don Salomón, to whom nobody wanted to return. Besides, the company gave us a courtesy while initiating the contract, but as the first contract was signed, 4,000 pesos were given to each person as an expenditure for the signature."

In general, one can speak of an explosion of powers and the birth of resistance dynamics.

"In the case of the company, they always tried to open negotiations and tried to understand our version without letting us understand that we are fighting because they lean towards the government. They are the people of the government, along with other authorities, who validate the environmental impacts and risk assessments and issue permits."

Finally, from the arrival to the present time, a vacuum was created, which made this project longer, beyond what was determined by law. Equally, the resistance was increasingly diverse; they lacked policy analysis, and the company came only with an economic analysis, so its resistance passed from one group to another, from one structure to another, from one actor to another, and from one conflict to another, assuming the expenditure load that came in between. This debate can be found with Keesing [50], who suggests, in the absence of political analysis by the actors, to call this displacement of resistance, as can be seen with this statement with which our debate concludes: "The arrival of the company here was not correct considering the support of Don Salomón and the authorities. They thought that we are easy to manage, which is not true, but now they have experienced so much that they suffered with us, and now we feel strong and with a power not only to have land that the company needs, but we still know what it is, and we can even negotiate for most of them because the companies live on the pity of us as poor, they know that we need those pennies"' (field, 2019-2020).

\subsubsection{Sociocultural Limitations for Sustainability and Absence of Energy Democracy}

Analyzing the approach to social liminalities from the role assumed by the community during implementation is one of the key axes of this work, where we can observe the social challenges that large companies faced in the framework of the energy transition. In the context of the global economy, we all know that the first objective to consider is the strengthening of capital, leaving incalculable environmental damage. However, we are facing the birth of a new sector with an alternative and sustainable discourse. That is why, from the case study, we will see those liminalities that this new sector faced without taking into account the sociocultural contexts, resulting in an absence of transparency and abuse of power that leaves us facing several stimulating questions that enrich the discussion and deepen the debate. Can we ask ourselves, then, to what extent was the company's project accepted, rejected, or negotiated, and how was the community's resistance process?

This discourse and position, as explained by some members of the community, developed slowly, and one of the factors that made it stronger is the procedure of how the consultations happened. 
"No one cared about being indigenous or not until the conflict grew, and then everyone took refuge in being Mayan, even the young people who live by working in Cancun". (field, 2019-2020)

In the same context and from the perspective of women, "Here, as the matter was given great importance, especially by the newspapers and young people on Facebook, we came to realize that being Mayan gives us rights; even though we have not been part of the ejido since then, we all empowered ourselves to be Mayans, to demand our rights, and to seek more benefits" (field, 2019-2020).

Instead, there were opinions where not only was the power of identity discussed, but they also expressed that today, with the arrival of megaprojects, the end of indigenous groups is coming.

"I don't expect any offer here. In that community, they only want to end the indigenous, the local, the original, but they also do not want anyone to remain Mayan. With their projects, they plan to end us; instead, nobody defends us". (field, 2019-2020)

It is necessary to mention that these contexts cannot be analyzed without considering the model of Michel Foucault [46-48], "Power and Resistance", in which analysis of power and resistance is offered in his works, from Discpline and Punish to the elaborations of the first volume of his History of Sexuality. According to Michel Foucault [46-48], "resistance is neither reactive nor negative, it is a process of creation and permanent mutation."

The proposed model shows that the dynamics of resistance are present not only in parts, but also in the levels of power, which means, according to its conception, that when there is power, there is resistance. This speaks of the naturalness of the process and means that, in the case of the community, a level of resistance was manifested because there were various forms and levels of power, as we showed earlier.

Seeing this conception, the social reaction from the ejido and the community is understood, which makes Foucault's [46-48] validity evident in any reflection on the resistance; with the subjects, it was possible to understand that the positions and the reactions would continue to be generated according to the power that arose, as the following statement shows.

"Here, in the case of San José, the reactions we had as a town, community, and ejido had a source. We did not do that emptily; we had reason to stop the sale. After hearing what the company said, we could not stop, even that is not above this group that is against it, who continue to fight due to their vision of where that bad weather takes us". (field, 2019-2020)

As they confirmed, the majority understood that resistance is like power. They showed that they became powerful because it was necessary; it was a power that arose from the power of the dominant and capitalist majority, a power that wants to manipulate them.

"I want to be honest with myself. Don Salomón did not pay us to accept and to sell the land; that's why when we knew what was going to happen, and thank God I went with time, we came to paralyze the presale where we had not only one chance, but several occasions to negotiate with the company". (field, 2019-2020)

This finding can be expressed in the content of the renowned interview conducted by Bernard Henry-Levy called "No to the Sex King", where Foucault [51] maintains that resistance is similar to power and that it closely resembles it [51]. This permanent parallelism of power and resistance is very clear and justified in the statements of the population of San José Tipceh.

"Here, it was not a created process that we sought to fight. It was since Don Salomón deceived us and upon learning that from the voice of the company, that, in the end, what he bought from us was rented. Our fight was not to leave that injustice against him, and afterwards against the same company, until negotiating what today, as a majority, we have signed with the presence of the government". (field, 2019-2020) 
In the same sense:

"Here, everything that the community did was right; it does not seem to me that they were right in that this group continues with their ideas, against which we have signed".

(field, 2019-2020)

It is possible to speak of resistances that show several faces (see Figure 6). They have been permanent; with the true power of the ejido and the community, the latter turned out to be a parallel power to the ejido power.

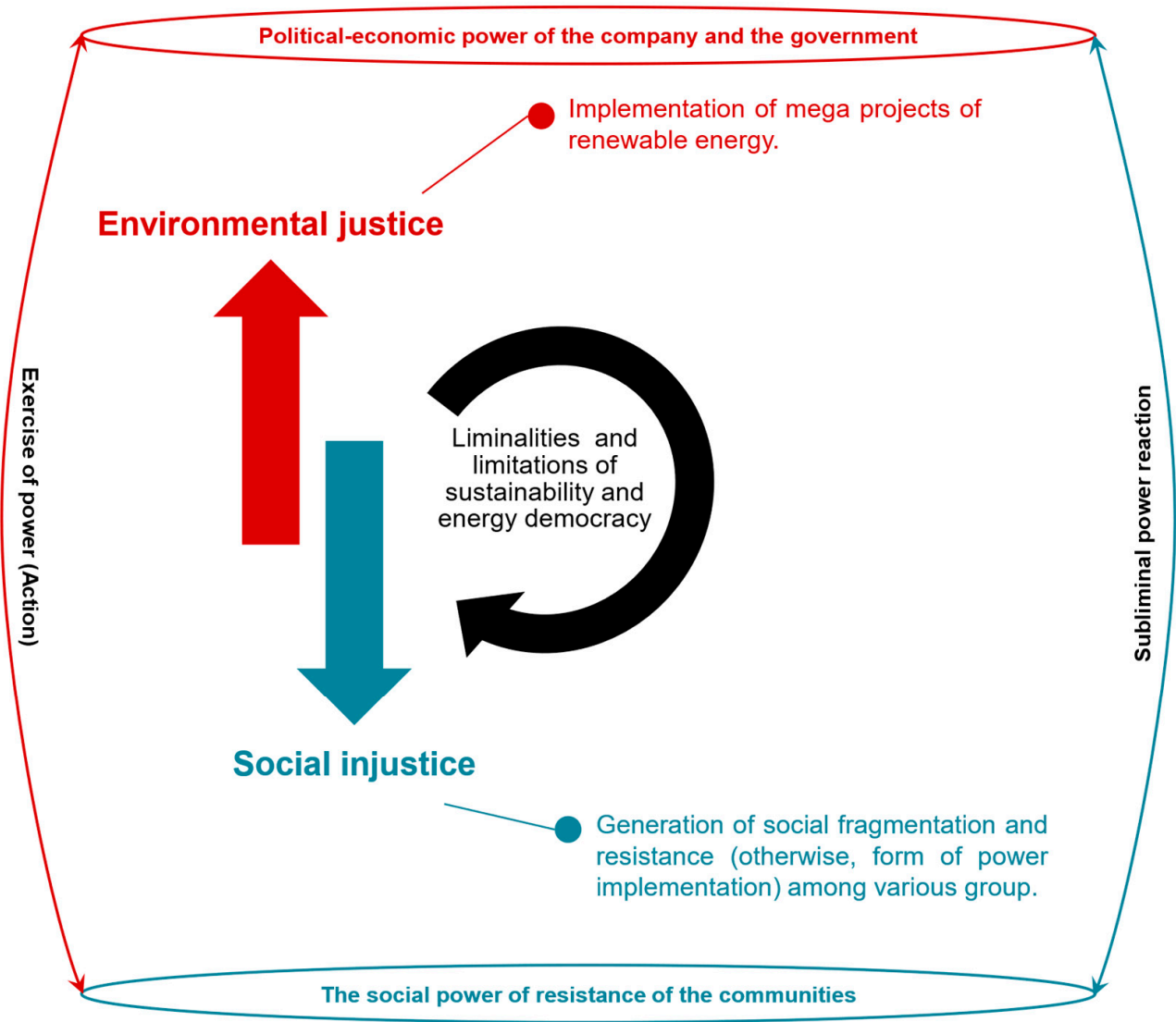

Figure 6. Findings of the work concluding that environmental justice and social justice can be in opposite directions owing to the liminalities and limitations of the implementation of sustainability plans, resulting in the political-economic power of the company and the government, as well as the social resistance of the communities.

"We got to do everything, fight, shout, press, negotiate, see for our economy, as a rural, indigenous community, that this territory belongs to us, and we can negotiate for it because, according to me, that which was necessary was done. The case of San José is already known; I do not need to speak, it is registered in any social network or newspaper page". (field, 2019-2020)

Resistance, as Foucault [46-48] expresses in his works, is not only parallel to power; according to us, it is even formulated into new types of powers. "Here, we are aware, and we will not go down until we achieve everything. The company comes to win and the community does not care because it offered better options and it saved us from failure, but in exchange for that, it will take away our identity with its ideas, its plans that are called social. I do not see that something is clear so that I can stop here; we must continue fighting until the end. I do not leave my community" (field, 2019-2020). 
"We can understand that the resistance was not stable. At all times, there is talk of some dynamics. It was contextual, but many times they said that the resistance did not have a balanced voice and that it was the same group that negotiated, demanding as a representative of the community, but in several consultations and assemblies, almost the same person and the same speech were spoken of, which sometimes led to lawsuits and disputes that could have been avoided". (field, 2019-2020)

Following the use of gender as a new face of resistance is a present theme equal to that of the rural community. "Here, we get to negotiate our rights, but we are not living badly; our basic work is as bricklayers. The women here do not work, they are always doing the chores at home; that gave us the right to negotiate, which was established from what the company says is a social project" (field, 2019-2020).

Supporting our analysis according to Foucault's ideas [46-48], this ends up being close to what the town of the San José Tipceh community refers to as the distribution of power. In its origin is resistance, where the interviewees expressed that there was a dynamic and order in the negotiations, and that most of them were tense; the authorities, according to the people, interfered to explain what was put up as a Mayan translation and what was oriented by speaking with the community's and town's commissioners. As can be determined from the discussion, according to Foucault, resistance is "inventive, mobile, and productive. Power needs to be organized, clotted, and grounded" [46-48].

Interestingly, we are facing a complex model just by describing the tension that occurred when talking about the energy transition, especially in the implementation of the Solar Park. The case study gives us a general idea of how the state and federal power came to play in this process, where power exists to measure and reconcile on several occasions and in the same consultations, as people say, or to establish discussions with the ejidatarios and community.

"Here, it was not easy to heal the wound from the beginning, but the authorities insisted that we continue to listen, above all, to the version of the same company. Here, the matter was discussed a lot. We were worried about if the company got fed up and the project was cancelled. I don't know how we are now that many of us have found work during the six months in which we cleaned the land; we have been collecting the rent for almost two years because, in the end, it still helps, but now we have sued the company and even SENER (Spanish abbreviation of Secretariat of Energy)". (field, 2019-2020)

In the majority of the field notes, the current level of the project is mentioned and the dynamics of the resistance as power are also discussed, especially now that it is concentrated at the level of ejidatarios as a minority, who came to sue the same company and even government structures for having implemented an unfair and manipulated consultation process.

\subsection{Sustainability and Gender Discrimination}

On September 25, 2015, more than 150 world leaders attended the United Nations Summit on Sustainable Development in New York to approve the Agenda for Sustainable Development. A total of 193 world leaders established the commitment to achieve 17 Goals for Sustainable Development (SDGs) for the year 2030, which are applicable to all the participating countries. Specifically, goal 5 of the SDGs refers to gender equality and the need to curb discrimination and violence against women and girls. International law has, for decades, banned all forms of discrimination based on gender. Indeed, the Universal Declaration of Human Rights of 1948, the Fundamental Charter of Human Rights formalized in 1975, and numerous international conventions in later decades reaffirm the principle of non-discrimination, stipulating that states must guarantee equal rights for men and women to enjoy all the fundamental rights in the social, political, labor, cultural, educational, economic, and health fields.

Now, from the social axis of sustainability, as established in 1987, the goal is the highest level of well-being. This implies education for all, access to water, food, health, decent housing, and a 
fair distribution of wealth. In other words, it is the search for equality. In recent decades, there has been no doubt that gender is an analytical category that must be transversal. Therefore, it has been incorporated into the international agenda through the Millennium Goals (MDGs) and now in the Sustainable Development Goals (SDGs). In 2013, for the first time in Mexico, it was incorporated as a transversal axis in the National Development Plan (2013-2018), as well as in the National Program for Equal Opportunities and Non-Discrimination against Women (PROIGUALDAD; 2013-2018) [52].

Unfortunately, despite all these international efforts, there are still great inequalities in the labor market, discrimination in decision-making in the public sphere, gender violence, and sexual exploitation, among other problems. In Mexico, it is still a remarkable reality, especially in the rural world, and in this article, we try to show some levels of this discrimination experienced by women, especially in the face of this new wave of the arrival of energy capitalism, which today is considered a great dynamic for a sustainable development that must protect environmental matters, preserve the rights of women, and establish the policies and strategies to achieve gender equality.

No one today can deny the vital role of clean energy and its indispensable role in our contemporary world. Its importance in the development process, its close connection with various fields of sustainable development, and its dimensions became evident. The case study presented in this research seeks to provide evidence on the existence of a significant relationship between hegemonic masculinity and economic rationality in decision-making.

At the first level, it can be said that the perspective of gender equality remained only a discourse without application, and that from the percentage of women's interventions in consultation meetings, it could be seen that the male voice dominated in negotiating, criticizing, demanding, and asking, and that is what the women declared. "I actually attended these meetings, but in total, I was late or shortly after they started, because we women feel that we are useless beings in expressing opinions or being part of the debate because sometimes, all the discussions were focused on what the economic benefit is and how the community will benefit in terms of money, leaving us somehow protected by our men in the form of husbands, fathers, or brothers." In the same sense, a 28-year-old mentioned, " ... because in the consultations talking about women's rights, for me, it was like a political discourse, that the project is here to improve the situation of women and empower them, but there were no meetings or contact with them to find out how we think about improving our conditions. In one way or another, it was a package that contains a plan for women, that is, it is part of the company's policy or the protocol required by the government."

Another dimension that seems very important to us while dealing with the issue of gender equality is that, in the community, most women follow what men decide. There is still a relationship of domination, such that the same women declared: "Here, even women cannot feel free. Everything is still in the hands of men; you can still notice the changes, but in big decisions, we are in second place."

Gender was a manipulated discourse; the group that was against the arrival of the energy project only used women to express their voices, and expressed that they are members of the community. In this regard, as declared by an ejidatario that "women generally do not have an opinion here, and especially if it is about large projects like this, but the fact is that we have heard women who oppose the company and renewable energy." The female voice was ultimately used for the resistance of this group to these new investment processes, which does not lead us to conclude that we are facing a discourse that was constructive, not only from the reality that we describe in the implementation of ethnography, but also from the dynamics of the subjects, especially some ejidatarios who are now the group against the megaproject and are advised by lawyers, academics, and even politicians.

It is a resistance that Foucault [46-48] describes in his theory that arose from logic, which can be explained using the data of the natural growth of a social process, where each force seeks to dominate more-a power where one seeks to establish profit without considering what the common order is.

When analyzing the promises of the same company to the community, one can speak of a third level where it can be seen that the gender perspective was a strategy of pressure in the consultation, using its nature as a social projects in its entirety, aimed at improving the family conditions and 
improving the situations of women; we can observe that in the following testimony: "In reality, the company spoke a lot about how the women of the project will benefit at an economic, social, and educational level, and how the women, for whom they left almost a hundred of the scholarships that are going to be given, could be the best resource managers. I do not see it as a decision that would improve. It seems to be a policy to convince us and women to accept the project."

It can be concluded from this section that the neoliberal economic system has been designed from an androcentric vision. Men play the main roles in decision-making, are in the most powerful positions, and have a direct negative or positive impact on sustainable development.

\section{Conclusions and Recommendations}

Through this work, we have analyzed the social conflicts generated between different sectors within an indigenous community upon the arrival of a megaproject for renewable energy. The work indicates that the approach for the implementation-from the global to the local—of energy projects generates uncertainties in human-centered sustainable development. Our study also describes a deployment scenario of the powers of different members of the indigenous community, the government, and the renewable energy company. A complex relationship between these actors and their implementations in various ways are illuminated. This shows us that, in communities with mobilization and cohesion capacity and with an interest in negotiating benefits, consultation is useful to negotiate better compensations.

The existence of patterns of inequality within this type of community is highlighted. Land tenure is generally not transferred to women, reducing their decision-making capacity at the assembly level, while men have generally migrated to the United States or have aged, and those who join the community (called residents) have no right to participate in assemblies. This implies the appearance of various conflicts, especially if community members negotiate benefits that deepen inequalities between themselves and residents.

The empowerment of ejidatarios and residents arises from the fact that the federal government authorities disclose the solar energy project because the law requires prior consultation with the community and their approval. Empowerment of the ejidatarios is because of the right that they formally have on the land where the project will be installed. Empowerment of residents is because of the protection of human rights in settlements near the project.

For the current situation, the residents of San José Tipceh (including ejidatarios) did not recognize themselves as an indigenous community as the government names it; they are not even a community (fighting for something in common). In this sense, the sustainability of the project is in danger in the long term, because once the negotiation period has passed and the project begins to function, the power of the community will tend to disappear.

We also proposed a framework (see Figure 7) to empower the local sociocultural context for an equitable energy transition of Mexico to strengthen the energy democracy and sustainability in the long term. We believe that the analyzed renewable energy project can leave deep social footprints between the community, the government, and companies. Therefore, a reverse sustainability approach must be implemented-from local needs to global strategies—along with direct and reverse feedback, which can help in the resolution of such conflicts. 


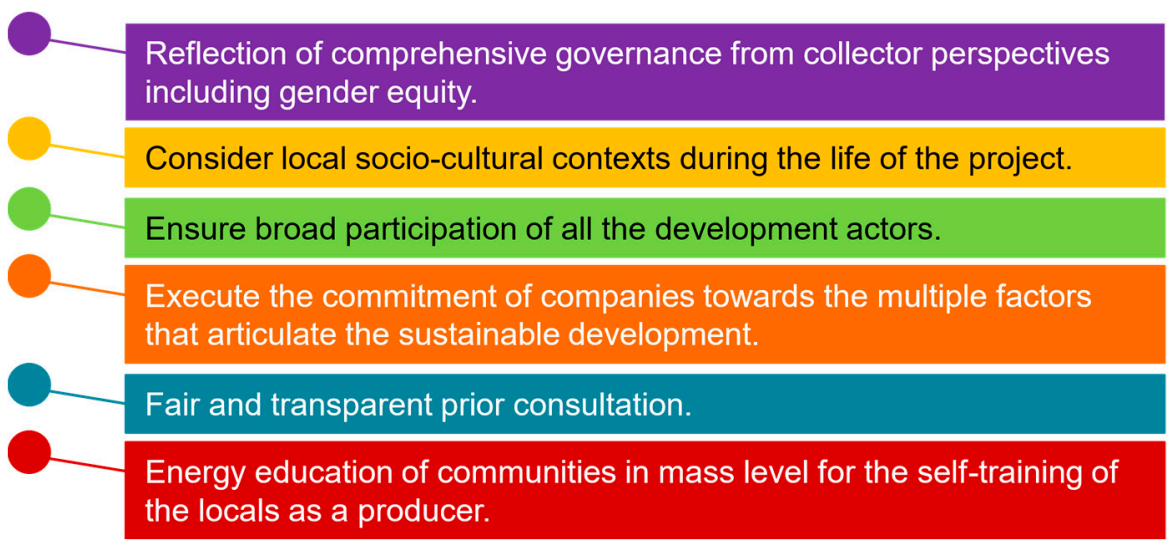

Figure 7. A framework to empower the local sociocultural context for an equitable energy transition.

Author Contributions: Conceptualization, A.E.M. and O.B.R.; methodology, A.E.M. and O.B.R.; software, A.E.M. and R.T.; validation, A.E.M., O.B.R., and R.T.; formal analysis, A.E.M., O.B.R., and R.T.; investigation, A.E.M., O.B.R., R.T., and P.E.M.-M.; resources, A.E.M.; data curation, A.E.M. and R.T.; writing-original draft preparation, A.E.M., O.B.R., and R.T.; writing-review and editing, A.E.M., O.B.R., R.T., and P.E.M.-M.; visualization, A.E.M. and O.B.R.; supervision, A.E.M. and O.B.R.; project administration, A.E.M. and O.B.R.; funding acquisition, A.E.M., O.B.R., and P.E.M.-M. All authors have read and agreed to the published version of the manuscript.

Funding: This research received no external funding.

Acknowledgments: The authors would like to acknowledge the support of CONACYT for the funding of Cathedral project no. 437, titled "(in Spanish) Hacia nuevas políticas sociales desde el sector energético en el estado de Yucatán"; this work was also supported by UNAM-PAPIIT IA102620.

Conflicts of Interest: The authors declare no conflict of interest.

\section{Appendix A}

The ejido is a form of land tenure that gained importance in Mexico after the Agrarian Reform. Members of an ejido are called ejidatarios. In the case of Yucatan, in 1937, the laborers in the Agave fourcroydes plantations were initially organized and received land through 247 collective ejidos [53,54].

\section{References}

1. UNEP. Decoupling Natural Resource Use and Environmental Impacts from Economic Growth; United Nations: New York, NY, USA, 2011; ISBN 9789280731675.

2. Brundtland, G.H. Our common future; Oxford University Press: Oxford, UK, 1987. [CrossRef]

3. Zander, P.; Kächele, H. Modelling multiple objectives of land use for sustainable development. Agric. Syst. 1999, 59, 311-325. [CrossRef]

4. United Nations. Transforming our world: The 2030 agenda for sustainable development. United Nations sustainable knowledge platform. Sustain. Dev. Goals 2015. Available online: https://sustainabledevelopment. un.org/post2015/transformingourworld (accessed on 2 May 2020).

5. Penadés-Plà, V.; Martínez-Muñoz, D.; García-Segura, T.; Navarro, I.J.; Yepes, V. Environmental and social impact assessment of optimized post-tensioned concrete road bridges. Sustainability 2020, 12, 4265. [CrossRef]

6. Tariq, R.; Sheikh, N.A.; Xamán, J.; Bassam, A. An innovative air saturator for humidification-dehumidification desalination application. Appl. Energy 2018, 228, 789-807. [CrossRef]

7. Tariq, R.; Sohani, A.; Xamán, J.; Sayyaadi, H.; Bassam, A.; Tzuc, O.M. Multi-objective optimization for the best possible thermal, electrical and overall energy performance of a novel perforated-type regenerative evaporative humidifier. Energy Convers. Manag. 2019, 198, 111802. [CrossRef]

8. Arana Landin, S. Social economy as the means to help achieve the targets of sustainable development goal 14. Sustainability 2020, 12, 4529. [CrossRef]

9. United Natioms. UNCED Earth Summit Agenda 21: The United Nations programme of action from Rio; CreateSpace: Lexington, KY, USA, 1992. [CrossRef] 
10. United Nations Sustainable Development Goals: Sustainable Development Knowledge Platform. 2019. Available online: sustainabledevelopment.un.org (accessed on 2 May 2020).

11. Rojas Quiñónez, C.M. Evolución de las Características y de los Principios del Derecho Internacional Ambiental y su Aplicación en Colombia-Derecho del Medio Ambiente, 1st ed.; Universidad Externado de Colombia: Bogotá, Colombia, 2004; ISBN 958-616-802-6. (In Spanish)

12. Alsayegh, M.F.; Abdul Rahman, R.; Homayoun, S. Corporate economic, environmental, and social sustainability performance transformation through ESG disclosure. Sustainability 2020, 12, 3910. [CrossRef]

13. Badia, F.; Bracci, E.; Tallaki, M. Quality and diffusion of social and sustainability reporting in Italian public utility companies. Sustainability 2020, 12, 4525. [CrossRef]

14. Tariq, R.; Xamán, J.; Bassam, A.; Ricalde, L.J.; Soberanis, M.A.E. Multidimensional assessment of a photovoltaic air collector integrated phase changing material considering Mexican Climatic conditions. Energy 2020, 209, 118304. [CrossRef]

15. Angel, J. Towards Energy Democracy: Discussions and Outcomes from an International Workshop. Available online: https://www.tni.org/en/publication/towards-energy-democracy (accessed on 2 May 2020).

16. Fraune, C.; Knodt, M. Sustainable energy transformations in an age of populism, post-truth politics, and local resistance. Energy Res. Soc. Sci. 2018. [CrossRef]

17. Hale, J.; Legun, K.; Campbell, H.; Carolan, M. Social sustainability indicators as performance. Geoforum 2019, 103, 47-55. [CrossRef]

18. Phondani, P.C.; Maikhuri, R.K.; Rawat, L.S.; Negi, V.S. Assessing farmers' perception on criteria and indicators for sustainable management of indigenous agroforestry systems in Uttarakhand, India. Environ. Sustain. Indic. 2020, 5, 100018. [CrossRef]

19. Meadows, J.; Annandale, M.; Ota, L. Indigenous Peoples' participation in sustainability standards for extractives. Land Use Policy 2019, 88, 104118. [CrossRef]

20. Karanasios, K.; Parker, P. Tracking the transition to renewable electricity in remote indigenous communities in Canada. Energy Policy 2018, 118, 169-181. [CrossRef]

21. Schwoerer, T.; Schmidt, J.I.; Holen, D. Predicting the food-energy nexus of wild food systems: Informing energy transitions for isolated indigenous communities. Ecol. Econ. 2020, 176, 106712. [CrossRef]

22. Fernández-Llamazares, Á.; Virtanen, P.K. Game masters and Amazonian Indigenous views on sustainability. Curr. Opin. Environ. Sustain. 2020, 43, 21-27. [CrossRef]

23. McEwan, C. Spatial processes and politics of renewable energy transition: Land, zones and frictions in South Africa. Political Geogr. 2017. [CrossRef]

24. Morrice, E.; Colagiuri, R. Coal mining, social injustice and health: A universal conflict of power and priorities. Health Place 2013. [CrossRef]

25. Bedi, H.P. “Lead the district into the light”: Solar energy infrastructure injustices in Kerala, India. Glob. Transit. 2019. [CrossRef]

26. Grossmann, K. Using conflicts to uncover injustices in energy transitions: The case of social impacts of energy efficiency policies in the housing sector in Germany. Glob. Transit. 2019. [CrossRef]

27. Andreas, J.J.; Burns, C.; Touza, J. Overcoming energy injustice? Bulgaria's renewable energy transition in times of crisis. Energy Res. Soc. Sci. 2018. [CrossRef]

28. Mueller, J.T.; Brooks, M.M. Burdened by renewable energy? A multi-scalar analysis of distributional justice and wind energy in the United States. Energy Res. Soc. Sci. 2020. [CrossRef]

29. The Lancet Planetary Health. Environmental racism: Time to tackle social injustice. Lancet Planet. Health 2018, 2, e462. [CrossRef]

30. Martinez, N. Resisting renewables: The energy epistemics of social opposition in Mexico. Energy Res. Soc. Sci. 2020, 70, 101632. [CrossRef]

31. Yuan, X.; Zuo, J.; Huisingh, D. Social acceptance of wind power: A case study of Shandong Province, China. J. Clean. Prod. 2015. [CrossRef]

32. Batel, S. Research on the social acceptance of renewable energy technologies: Past, present and future. Energy Res. Soc. Sci. 2020, 68, 101544. [CrossRef]

33. Behrsin, I. Controversies of justice, scale, and siting: The uneven discourse of renewability in Austrian waste-to-energy development. Energy Res. Soc. Sci. 2020. [CrossRef]

34. Samarakoon, S. The troubled path to ending darkness: Energy injustice encounters in Malawi's off-grid solar market. Energy Res. Soc. Sci. 2020, 69, 101712. [CrossRef] 
35. Cordoves-Sánchez, M.; Vallejos-Romero, A. Social construction of risk in non-conventional renewable energy: Risk perception as a function of ecosystem services in La Araucanía, Chile. Ecol. Econ. 2019, 159, 261-270. [CrossRef]

36. Velasco-Herrejon, P.; Bauwens, T. Energy justice from the bottom up: A capability approach to community acceptance of wind energy in Mexico. Energy Res. Soc. Sci. 2020, 70, 101711. [CrossRef]

37. Carbajo, R.; Cabeza, L.F. Sustainability and social justice dimension indicators for applied renewable energy research: A responsible approach proposal. Appl. Energy 2019, 252, 113429. [CrossRef]

38. Fobissie, E.N.; Inc, F. The role of environmental values and political ideology on public support for renewable energy policy in Ottawa, Canada. Energy Policy 2019, 134, 110918. [CrossRef]

39. Zárate-Toledo, E.; Patiño, R.; Fraga, J. Justice, social exclusion and indigenous opposition: A case study of wind energy development on the Isthmus of Tehuantepec, Mexico. Energy Res. Soc. Sci. 2019. [CrossRef]

40. Mejía-Montero, A.; Alonso-Serna, L.; Altamirano-Allende, C. The role of social resistance in shaping energy transition policy in Mexico: The case of wind power in Oaxaca. In The Regulation and Policy of Latin American Energy Transitions; Elsevier: Amsterdam, The Netherlands, 2020; pp. 303-318.

41. Scott, J.C. The Moral Economy of the Peasant: Rebellion and Subsistence in Southeast Asia on JSTOR. Available online: https://www.jstor.org/stable/j.ctt1bh4cdk (accessed on 4 July 2020).

42. Montilla, L.E. Reseña: Resistir al Poder; Universidad Autónoma de Bucaramanga: Bucaramanga, Colombia, 2002.

43. Scott, J.C. Weapons of the Weak: Everyday Forms of Peasant Resistance on JSTOR. Available online: https://www.jstor.org/stable/j.ctt1nq836 (accessed on 4 July 2020).

44. Giddens, A. The constitution of society: Outline of the theory of structuration: Elements of the theory of structuration. In Practicing History: New Directions in Historical Writing after the Linguistic Turn; Routledge: London, UK, 2004; ISBN 9780203335697.

45. Adams, R. La ética y el antropólogo social en América Latina. Am. Behav. Sci. 1967, 10, 16-21. (In Spanish) [CrossRef]

46. Foucault, M. Del poder de Soberanía al Poder Sobre la vida. In Geneaología del Racismo (Original Title: Il faut Défendre la Société); Editorial Altamira: Plata, Argentina, 1976; ISBN 987-9017-01-3. Available online: https://www.exapuni.com/carreras/apunteHash/4be06ad644d2fc68575267cd2bce99cc (accessed on 1 September 2020). (In Spanish)

47. Foucault, M. Undécima Lección. In Geneaología del Racismo (Original Title: Ilfaut Défendre la Société); Editorial Altamira: La Plata, Argentina, 2006; ISBN 9879017013. Available online: https://www.academia.edu/ 34719954/Foucault_Michel_GENEALOG\%C3\%8DA_DEL_RACISMO_pdf (accessed on 1 September 2020). (In Spanish)

48. Foucault, M. Un Diálogo Sobre el Poder y Otras Conversaciones, 7th ed.; El libro de Bolsillo Alianza Editorial: Madrid, Spain, 2000; Available online: https://museo-etnografico.com/pdf/puntodefuga/181003focault2.pdf (accessed on 1 September 2020). (In Spanish)

49. Ortner, S.B. Resistance and the Problem of Ethnographic Refusal. Comp. Stud. Soc. Hist. 1995, 37, $173-193$. [CrossRef]

50. Burt, B.; Keesing, R.M. Custom and confrontation: The Kwaio struggle for cultural autonomy. Man 1994. [CrossRef]

51. Lévy, B.-H. Foucault: No al Sexo Rey. 1977. Available online: https://gredos.usal.es/handle/10366/66655 (accessed on 1 September 2020). (In Spanish).

52. Fernández-Kelly, P. Reforming Gender: The effects of economic change on masculinity and femininity in Mexico and the US. Women Stud. Rev. 2005, 69-101. Available online: https://cw.lehman.edu/academics/ inter/women-studies/documents/reforming-gender.pdf (accessed on 1 September 2020).

53. Baños Ramírez, O. Yucatán: Ejidos Sin Campesinos; Estudios Sociológicos de El Colegio de México; Universidad Autónoma de Yucatán: Mérida, Yucatán, Mexico, 1989; Available online: https://estudiossociologicos.colmex. mx/index.php/es/article/view/1105 (accessed on 21 June 2020).

54. Eckstein, S. El Ejido Colectivo en México, 1st ed.; Fondo de Cultura Económica: Distrito Federal, Mexico, 1966.

(C) 2020 by the authors. Licensee MDPI, Basel, Switzerland. This article is an open access article distributed under the terms and conditions of the Creative Commons Attribution (CC BY) license (http://creativecommons.org/licenses/by/4.0/). 